\title{
High Antarctic macrobenthic community production ${ }^{1}$
}

\author{
Thomas Brey*, Dieter Gerdes \\ Alfred Wegener Institute for Polar and Marine Research, P.O. Box 120161, D-27576 Bremerhaven, \\ Germany
}

Received 14 August 1997; received in revised form 3 March 1998; accepted 21 March 1998

\begin{abstract}
Production and productivity $(P / B$ ratio) of the high Antarctic Weddell Sea and Lazarev Sea macrozoobenthos are estimated by an empirical multiple non-linear model (artificial neural network) based on biomass data and other biotic and abiotic parameters. Average community production decreases with depth from $4.8 \mathrm{~g} \mathrm{C} \mathrm{m}^{-2}$ year $^{-1}(100-300 \mathrm{~m})$ to $0.1 \mathrm{~g} \mathrm{C} \mathrm{m}^{-2}$ year $^{-1}$ (1500-4300 m). Community $P / B$ ratio increases with depth from 0.18 year $^{-1}$ to 0.55 year $^{-1}$. Taking into account the effects of water depth on production and of temperature on $P / B$ ratio, Antarctic communities show no evidence of unique characteristics with respect to overall energy flow. (c) 1998 Elsevier Science B.V. All rights reserved.
\end{abstract}

Keywords: Antarctica; Benthic Invertebrates; Benthic Production

\section{Introduction}

In the high-Antarctic ecosystem the benthos is assumed to play a significant role in energy flow and matter cycling (Schalk et al., 1993; Jarre-Teichmann et al., 1997). The limited access to these regions and the extremely high number of species present (e.g. Arntz et al., 1994), however, make any thorough community energy flow study a process stretching easily over decades. Previous estimates of benthic community energy flow in the Weddell Sea are either indirect ones (Schalk et al., 1993) or based on the still very limited information on population productivity (Jarre-Teichmann et al., 1997).

In the present study we estimate production and productivity of the Weddell Sea and Lazarev Sea macrobenthos by an empirical approach and compare our results with non-Antarctic benthic community production data.

\footnotetext{
*Corresponding author. E-mail: tbrey@awi-bremerhaven.de (www: http://www.awi-bremerhaven.de)

${ }^{1}$ This is Alfred Wegener Institute Publication No. 1361.
} 


\section{Methods}

\subsection{Data collection and treatment}

During the 'RV Polarstern' expeditions ANT VI/3, ANT VII/4 and ANT IX/3, 54 stations in the Weddell Sea and Lazarev Sea (Fig. 1) were sampled by the multi-box corer (Gerdes, 1990; Gerdes et al., 1992) which collects nine boxes of $240 \mathrm{~cm}^{2}$ each simultaneously. The stations covered a depth range from 132 to $4293 \mathrm{~m}$ water depth and were grouped into five depth strata according to Table 1 . On average seven of the nine boxes sampled per station (i.e. $1680 \mathrm{~cm}^{2}$ surface area) were used for macrobenthic analysis. The samples were sieved on $0.5 \mathrm{~mm}$ mesh size and stored in $4 \%$ formaldehyde solution buffered with hexamethylenetetramine.

In the laboratory, animals were sorted and identified to 38 taxonomic groups (Table 2 ). Abundance and wet biomass per group were determined. We converted the wet mass data to $\mathrm{g} \mathrm{C}_{\text {org }}$ and $\mathrm{kJ}$ using conversion factors for major taxonomic groups derived from Cummins and Wuycheck (1971), Dayton et al. (1974), Atkinson and Wacasey (1976), Steimle and Terranova (1985), Rumohr et al. (1987), Salonen et al. (1976), Wacasey and Atkinson (1987), Walker et al. (1987), Brey et al. (1988), Dauvin and Joncourt (1989), Barthel (1995), and Dahm (1996) and Refs. therein.

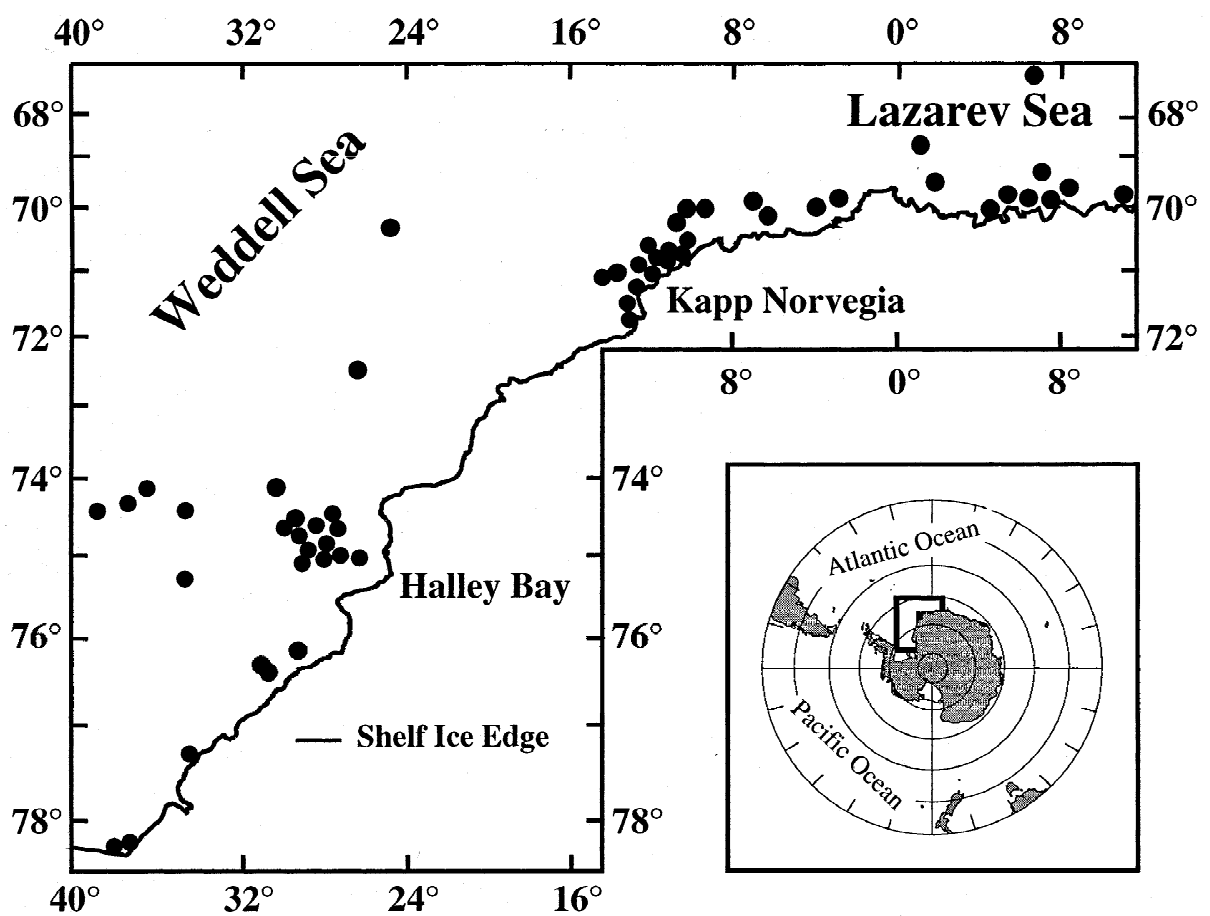

Fig. 1. Location of stations in the Weddell Sea and the Lazarev Sea. 
Table 1

Depth distribution, mean temperature and macrobenthic abundance and biomass of stations in the Weddell and Lazarev seas sampled with the multi box corer

\begin{tabular}{llllll}
\hline $\begin{array}{l}\text { Depth } \\
\text { range } \\
(\mathrm{m})\end{array}$ & $\begin{array}{l}\text { No. of } \\
\text { stations }\end{array}$ & $\begin{array}{l}\text { Mean } \\
\text { temp. } \\
\left({ }^{\circ} \mathrm{C}\right)\end{array}$ & $\begin{array}{l}\text { Mean } \\
\text { no. ind. } \\
\mathrm{m}^{-2}\end{array}$ & $\begin{array}{l}\text { Mean } \\
\text { Biomass } \\
\left(\mathrm{g} \mathrm{C} \mathrm{m}^{-2}\right)\end{array}$ & $\begin{array}{l}\text { Range } \\
\left(\mathrm{g} \mathrm{C} \mathrm{m}^{-2}\right)\end{array}$ \\
\hline $100-300$ & 11 & -1.8 & 6964 & 26.83 & $0.79-45.14$ \\
$300-500$ & 20 & -1.8 & 4102 & 4.64 & $<0.01-16.73$ \\
$500-700$ & 12 & -1.0 & 3205 & 8.05 & $0.22-58.45$ \\
$700-1500$ & 6 & -0.5 & 2464 & 1.40 & $<0.01-3.67$ \\
$1500-4300$ & 5 & +0.5 & 254 & 0.16 & $<0.01-0.62$ \\
\hline
\end{tabular}

Temperature data are taken from Gerdes (unpublished data).

Table 2

The 38 taxonomic groups used for estimates of annual $P / B$ ratio

\begin{tabular}{llll}
\hline Porifera (1) & Polyplacophora (6) & Acari (8) & Echinoidea (9) \\
Hydrozoa (2) & Aplacophora (6) & Pantopoda (8) & Holothuroidea (9) \\
Anthozoa (2) & Bivalvia (6) & Amphipoda (8) & Asteroidea (9) \\
Bryozoa (3) & Gastropoda (6) & Cumacea (8) & Ophiuroidea (9) \\
Brachiopoda (3) & Solenogastrea (6) & Harpacticoidea (8) & Crinoidea (9) \\
Sipunculida (4) & Scaphopoda (6) & Cirripedia (8) & Hemichordata (10) \\
Turbellaria (5) & Polychaeta (7) & Isopoda (8) & Tunicata (11) \\
Nemertinea (5) & Oligochaeta (7) & Tanaidacea (8) & Others (12) \\
Priapulida (5) & Hirudinea (7) & Ostracoda (8) & \\
Vermes spp. (5) & Echiurida (7) & Crustacea spp. (8) & \\
\hline
\end{tabular}

The numbers in brackets indicate the 12 major taxonomic groups used for data representation (Fig. 2).

\subsection{Estimation of annual production/biomass ratio and production}

Brey et al. (1996) estimated annual population $P / B$ ratio from easy-to-obtain parameters such as mean body mass, living mode, feeding type, taxon, water depth and temperature (Table 3) by means of artificial neural networks, which are a specific multivariate non-linear approach. Annual production was subsequently computed from $P / B$ and population biomass. The authors showed the sum of population production values obtained by this approach to be a reasonable estimate of community production.

Table 3

Parameters used to estimate population $P / B$ ratio by artificial neural networks

\begin{tabular}{ll}
\hline Parameter Group & Parameter \\
\hline Abiotic Parameters & Mean annual temperature $T(\mathrm{~K})$ \\
& Water depth $D(\mathrm{~m})$ \\
Biotic Parameters & Mean ind. bodymass $M(\mathrm{~kJ})$ \\
Motility & Vagile-Sessile \\
Living & Epifauna-Infauna \\
Feeding & Herbivorous, omnivorous, carnivorous \\
Biotop & Marine, river, lake \\
Taxon & Mollusca, Crustacea, Polychaeta, Echinodermata, insecta larvae, others \\
\hline
\end{tabular}


Due to the extremely large number of species present, we were not able to work at the population level, but used the 38 taxonomic groups of Table 1 as population units. Within each depth stratum we computed or determined the parameters mentioned above for these groups and used the artificial neural networks of Brey et al. (1996) to estimate $P / B$ per group. Production of each group was computed by multiplying $P / B$ with average biomass. The sum of these values resulted in community production per depth stratum.

\section{Results}

Biomass $(B)$, production $(P)$ and productivity $(P / B)$ data are summarised in Fig. 2. Benthic biomass decreases from $26.83 \mathrm{~g} \mathrm{C} \mathrm{m}^{-2}$ in the $100-300 \mathrm{~m}$ stratum to $0.16 \mathrm{~g} \mathrm{C}$ $\mathrm{m}^{-2}$ in the 1500-4300 $\mathrm{m}$ stratum. Community production decreases accordingly with depth from $4.83 \mathrm{~g} \mathrm{C} \mathrm{m}^{-2}$ year $^{-1}$ to $0.09 \mathrm{~g} \mathrm{C} \mathrm{m}^{-2}$ year $^{-1}$. Annual $P / B$ ratio, however, increases with depth from 0.18 year $^{-1}$ in the $100-300 \mathrm{~m}$ stratum to 0.55 year $^{-1}$ in the $1500-4300 \mathrm{~m}$ stratum.

The distribution of $B$ and $P$ among the 12 major taxonomic groups shown in Fig. 2 indicates that in the $100-300 \mathrm{~m}$ stratum community standing stock and energy flow is dominated by sponges ( $54 \%$ of total $B, 45 \%$ of total $P$ ), but in deeper waters by annelids (8-47\% of $B, 22-61 \%$ of $P$ ) and/or echinoderms (11-73\% of $B, 11-47 \%$ of $P$ ).

\section{Discussion}

\subsection{Methods}

From a statistical point of view, the number of stations per depth stratum is rather low, as indicated by the high variability of biomass data (Table 1). As any grab or corer, the multi-box corer (MBC) potentially underestimates abundance and biomass of large but comparatively rare species (e.g. ophiuroids, see Dahm, 1996), as well as of highly mobile species which may escape from the approaching gear (e.g. decapods, see Gutt et al., 1991). These problems can be overcome partially either by largely increasing the number of samples, an approach limited by available shiptime and manpower, or by combining different sampling techniques, as demonstrated by Dahm (1996) and Piepenburg et al. (1995).

Dahm (1996) showed that MBC underestimated biomass of ophiuroids by a factor of about 3 on the Weddell Sea shelf and slope. A three-fold increase of ophiuroid biomass would change only the community figures in the $1500-4300 \mathrm{~m}$ stratum distinctly $\left(B=0.32 \mathrm{~g} \mathrm{C} \mathrm{m}^{-2}, P=0.15 \mathrm{~g} \mathrm{C} \mathrm{m}^{-2}\right.$ year $^{-1}, P / B=0.48$ year $\left.^{-1}\right)$, but it is not known if this correction factor is valid for this depth range, too. Generally we are not able to correct our biomass data appropriately to eliminate bias due to undersampling by the MBC, because no correction factors are available. Therefore our production figures should be interpreted as minimum estimates. Nevertheless, most other studies on 
Biomass

Production
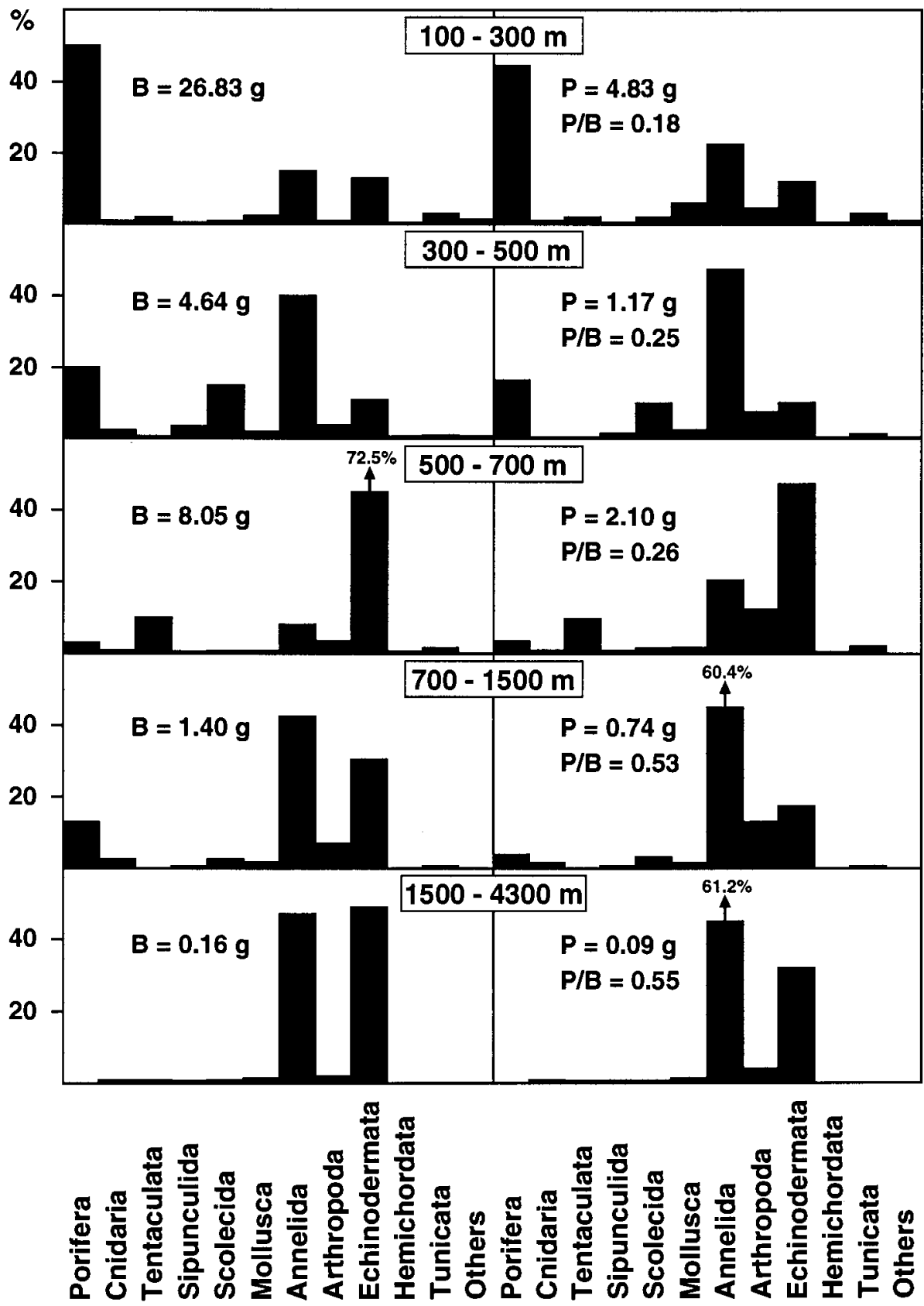

Fig. 2. Mean biomass $\left(\mathrm{g} \mathrm{C} \mathrm{m}^{-2}\right)$, annual production $\left(\mathrm{g} \mathrm{C} \mathrm{m}^{-2}\right.$ year $\left.{ }^{-1}\right)$ and $P / B$ ratio (year $\left.{ }^{-1}\right)$ of macrozoobenthos in different depth strata of the Weddell and Lazarev Sea. Histograms indicate distribution of biomass and production among 12 major taxonomic groups which are composed of the 38 groups the computations are based on. 
community metabolism suffer from similar shortcomings (see Refs. in Fig. 3) and are thus comparable with our data.

The artificial neural networks of Brey et al. (1996) were trained with 899 data sets $(\approx 400$ species $)$ referring to populations inhabiting temperature regimes between -1.8 and $30^{\circ} \mathrm{C}$, and water depths between zero and $2800 \mathrm{~m}$ and hence are assumed to be suitable for application to polar shelf and slope data. These models were designed for
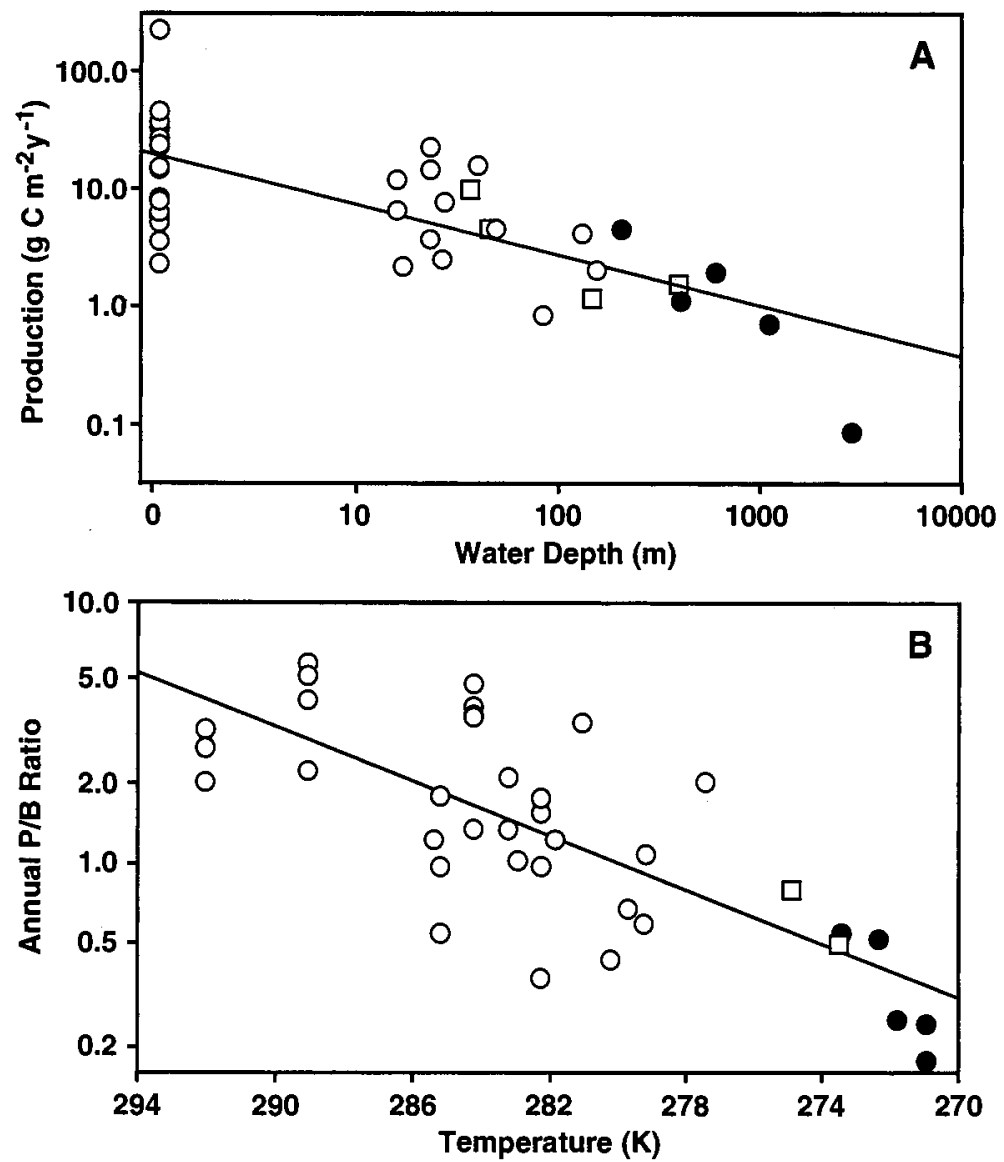

Fig. 3. Annual macrobenthic community production and $P / B$ ratio. Multiple linear regression of $P$ and $P / B$ versus water depth and temperature. Black dots, Weddell and Lazarev Sea; squares, Arctic; circles, non-polar data. (A) Annual production related to water depth (no significant effect of temperature, no significant interaction): $\log (P)=1.273-0.419 \cdot \log (D+1) ; r^{2}=0.524 ; P<0.001 ; n=39$. (B) Annual $P / B$ ratio related to temperature (no significant effect of water depth, no significant interaction): $\log (P / B)=14.497-4051.386$. $1 / T ; r^{2}=0.554 ; P<0.001 ; n=37$. Data are taken from Asmus (1987), Baird and Milne (1981), Brey and Gerdes (in press), Buchanan and Warwick (1974), Cederwall (1977), Elliott and Taylor (1989), George and Warwick (1985), Grebmeier et al. (1989), Grebmeier and McRoy (1989), Howe and Leathem (1984), Jackson et al. (1985), Piepenburg et al. (1995), Sardá et al. (1995), Sprung (1993), Steimle (1985), Steimle (1987), Theroux and Grosstein (1987), Warwick and George (1980), Warwick and Price (1975), Warwick et al. (1978), Warwick et al. (1979), Wolff and de Wolf (1977). 
use with population data but were applied to larger taxonomic units here (Table 1). This may have caused a decrease in accuracy of the estimates of community productivity and production, but not necessarily a bias towards under- or overestimation of $P / B$ and $P$.

\subsection{Production and productivity}

Our average community production figures, 4.8-0.1 $\mathrm{g} \mathrm{C} \mathrm{m}^{-2}$ year $^{-1}$ (Fig. 2), confirm previous estimates of Weddell Sea macrobenthic production. Based on sedimentation rates, Schalk et al. (1993) estimated $P \approx 0.3$ to $7.5 \mathrm{~g} \mathrm{C} \mathrm{m}^{-2}$ year $^{-1}$, whereas the balanced energy flow shelf model of Jarre-Teichmann et al. (1997) extrapolated from the few known species $P / B$ ratios to $P \approx 10 \mathrm{~g} \mathrm{C} \mathrm{m}^{-2}$ year $^{-1}$.

A comparison of Antarctic and Arctic shelf community production can be derived from Piepenburg et al. (1995), who measured daily respiration rates of Barents Sea benthic communities in a comparable depth range. Assuming the summer rates measured to be valid for about 100 days year ${ }^{-1}$ and the relation between production and respiration to be $P \approx 0.87 \cdot R$ (Humphreys, 1979), annual production of Barents Sea macro/megabenthos amounts to about $0.8 \mathrm{~g} \mathrm{C} \mathrm{m}^{-2}$ year $^{-1}$ ('shallow' stations, 80-240 $\mathrm{m}$ ) and $1.1 \mathrm{~g} \mathrm{C} \mathrm{m}^{-2}$ year $^{-1}$ ('deep' stations, 119-550 m), respectively. These values are similar to Weddell and Lazarev Sea production in the 300-500 m depth stratum $(1.2 \mathrm{~g} \mathrm{C}$ $\mathrm{m}^{-2}$ year $\left.^{-1}\right)$, but distinctly below the figures in the $100-300 \mathrm{~m}$ depth stratum $(4.8 \mathrm{~g} \mathrm{C}$ $\mathrm{m}^{-2}$ year $^{-1}$ ) and the 500-700 $\mathrm{m}$ depth stratum (2.1 $\mathrm{g} \mathrm{C} \mathrm{m}^{-2}$ year $\left.^{-1}\right)$. Unfortunately, Piepenburg et al. (1995) do not provide biomass data for the total macro/megafauna, and hence we cannot decide whether the Barents Sea community shows lower biomass or lower $P / B$ ratio than the Weddell and Lazarev Sea community. Interestingly, large mobile epibenthic organisms contribute significantly to total energy flow in both systems (mainly ophiuroids in the Arctic; all echinoderm classes in the Antarctic, Fig. 2). In the Barents Sea, however, the share of ophiuroids decreases sharply with water depth ('shallow' stations: 21\%, 'deep' stations: 3\%), whereas in the Weddell and Lazarev Sea the share of echinoderms is $>10 \%$ (ophiuroids 3-7\%) irrespective of depth.

To determine whether Antarctic benthic energy flow is affected by factors unique to the Antarctic, we applied multiple regressions (dependent variables, $\log (P)$ and $\log (P /$ $B)$; independent variables, $\log (D+1), 1 / T, \log (D+1) \cdot 1 / T)$ to data on Antarctic, Arctic and non-polar macrobenthic community production. This analysis revealed two significant relationships.

(i) Community production decreases exponentially with water depth (Fig. 3A). This decrease is well documented for macrobenthic biomass (e.g. Brey and Gerdes, 1997), but hitherto not for benthic production. The most likely explanation is the exponentially decreasing food input to the benthos with increasing water depth (Rowe, 1971; Suess, 1980).

(ii) Community $P / B$ ratio increases exponentially with water temperature (Fig. 3b). Obviously, the exponential relation between temperature and metabolism (e.g. Robinson et al., 1983; Ikeda, 1985), is reflected not only on the level of population $P / B$ ratios (e.g. Tumbiolo and Downing, 1994; Brey et al., 1996), but also in community $P / B$ ratios. Brey and Clarke (1993) found population $P / B$ ratios to be negatively related to water 
depth. In our small sample $(n=35)$, community $P / B$ ratios are not significantly related to depth. Moreover, in the Weddell and Lazarev Sea, community $P / B$ ratio rises with increasing water depth (Fig. 2). This is likely to be due to the increase of temperature and the decrease in average body mass with depth (Table 1).

Our data refer to the deepest and coldest sites which community production estimates are available from, and hence they represent the lowest figures of production and $P / B$ ratio in Fig. 3. Nevertheless, neither production nor $P / B$ ratio of the Antarctic (as well as of the Arctic) macrobenthos are outstandingly low, if we take into account the effects of water depth and of temperature on $P$ and $P / B$ ratio. That is, as shown previously for Antarctic benthic populations (Brey and Clarke, 1993), Antarctic benthic communities show no evidence of unique intrinsic characteristics with respect to overall energy flow, At the community level, adaptations to the particular environmental conditions of the Antarctic seem to be restricted to faunal composition (Brey and Gerdes, 1997) and trophic structure (Jarre-Teichmann et al., 1997) of the shelf and slope benthos.

\section{References}

Arntz, W.E., Brey, T., Gallardo, V.A., 1994. Antarctic Zoobenthos. Oceanogr. Mar. Biol. Annu. Rev. 32, 241-304.

Asmus, H., 1987. Secondary production of an intertidal mussel bed community related to its storage and turnover compartments. Mar. Ecol. Progr. Ser. 39, 251-266.

Atkinson, E.G., Wacasey, J.W., 1976. Caloric values of zoobenthos and phytobenthos from the Canadian Arctic. Fish. Mar. Service Tech. Rep. 632, 1-23.

Baird, D., Milne, H., 1981. Energy flow in the Ythan Estuary, Aberdeenshire, Scotland. Estuarine Coastal Shelf Sci. 13, 455-472.

Barthel, D., 1995. Tissue composition of sponges from the Weddell Sea, Antarctica: not much meat on the bones. Mar. Ecol. Progr. Ser. 123, 149-153.

Brey, T., Clarke, A., 1993. Population dynamics of marine benthic invertebrates in Antarctic and subantarctic environments: are there unique adaptations?. Antarctic Sci. 5, 253-266.

Brey, T., Gerdes, D., 1997. Is Antarctic benthic biomass really higher than elsewhere?. Antarctic Sci. 9, 266-267.

Brey, T., Gerdes, D., in press. Benthic community productivity in the Magellan region and in the Weddell Sea. IBMANT Symposium 1996, Punta Arenas, Chile. Scientia Marina.

Brey, T., Rumohr, H., Ankar, S., 1988. Energy content of macrobenthic invertebrates: General conversion factors from weight to energy. J. Exp. Mar. Biol. Ecol. 117, 271-278.

Brey, T., Jarre-Teichmann, A., Borlich, O., 1996. Artificial neural network versus multiple linear regression: predicting $P / B$ ratios from empirical data. Mar. Ecol. Progr. Ser. 140, 251-256.

Buchanan, J.B., Warwick, M.R., 1974. An estimate of benthic macrofaunal production in the offshore mud of the Northumberland coast. J. Mar. Biol. Assoc. UK 54, 197-222.

Cederwall, H., 1977. Annual macrofauna production of a soft bottom in the Northern Baltic Proper. In: Keegan, B.F. (Ed.), Biology of Benthic Organisms. Pergamon, Oxford, pp. 155-164.

Cummins, K.W., Wuycheck, J.C., 1971. Caloric equivalents for investigations in ecological energetics. Int. Assoc. Theor. Appl. Limnol. Commun. 18, 1-158.

Dahm, C., 1996. Ökologie und Populationsdynamik antarktischer Ophiuroiden (Echinodermata) (Ecology and population dynamics of Antarctic ophiuroids). Ber. Polarforsch. 194, 1-289.

Dauvin, J.-C., Joncourt, M., 1989. Energy values of marine benthic invertebrates from the Western English Channel. J. Mar. Biol. Assoc. UK 69, 589-595.

Dayton, P.K., Robillard, G.A., Paine, R.T., Dayton, L.B., 1974. Biological accommodation in the benthic community at McMurdo Sound, Antarctica. Ecol. Monogr. 44, 105-128. 
Elliott, M., Taylor, C.J.L., 1989. The production ecology of the subtidal benthos of the Forth Estuary, Scotland (Proc. 22nd Eur. Mar. Biol. Symp.). Sci. Mar. 53, 531-541.

George, C.L., Warwick, R.M., 1985. Annual macrofauna production in a hard-bottom reef community. J. Mar. Biol. Assoc. UK 713-735.

Gerdes, D., 1990. Antarctic trials of the multi-box corer, a new device for benthos sampling. Polar Record 26, 35-38.

Gerdes, D., Klages, M., Arntz, W.E., Herman, R.L., Galéron, J., Hain, S., 1992. Quantitative investigations on macrobenthos communities of the southeastern Weddell Sea shelf based on multi box corer samples. Polar Biol. 12, 291-301.

Grebmeier, J.M., McRoy, C.P., 1989. Pelagic-benthic coupling on the shelf of the northern Bering and Chukchi Seas. III. Benthic food supply and carbon cycling. Mar. Ecol. Progr. Ser. 53, 79-91.

Grebmeier, J.M., Feder, H.M., McRoy, C.P., 1989. Pelagic-benthic coupling on the shelf of the northern Bering and Chukchi Seas. II. Benthic community structure. Mar. Ecol. Progr. Ser. 51, 253-268.

Gutt, J., Gorny, M., Arntz, W., 1991. Spatial distribution of Antarctic shrimps (Crustacea: Decapoda) by underwater photography. Antarctic Sci. 3, 363-369.

Howe, S., Leathem, W., 1984. Secondary production of benthic macrofauna at three stations of Delaware Bay and coastal Delaware. NOAA Technical Memorandum NMFS-F/NEC-32, Woods Hole, USA, 62 pp.

Humphreys, W.F., 1979. Production and respiration in animal populations. J. Anim. Ecol. 48, 427-453.

Ikeda, T., 1985. Metabolic rate of epipelagic marine zooplankton as a function of body mass and temperature. Mar. Biol. 85, 1-11.

Jackson, D., Mason, C.F., Long, S.P., 1985. Macro-invertebrate populations and production on a salt-marsh in east England dominated by Spartina anglica. Oecologia 65, 406-411.

Jarre-Teichmann, A., Brey, T., Bathmann, U.V., Dahm, C., Dieckmann, G.S., Gorny, M., Pagès, F., Plötz, J., Schnack-Schiel, S., Stiller, M., Arntz, W.E., 1997. Trophic flows in the benthic shelf community of the eastern Weddell Sea. In: Battaglia, B., Valencia, J., Walton, D.W.H. (Eds.), Antarctic Communities. Cambridge University Press, Cambridge, pp. 118-134.

Piepenburg, D., Blackburn, T.H., Dorrien, C.F., von Gutt, J., Hall, P.O., Hulth, S., Kendall, M.A., Opalinski, K.W., Rachor, E., Schmid, M.K., 1995. Partitioning of benthic community respiration in the Arctic (northwestern Barens Sea). Mar. Ecol. Progr. Ser. 118, 199-213.

Robinson, W.R., Peters, R.H., Zimmerman, J., 1983. The effects of body size and temperature on metabolic rate of organisms. Can. J. Zool. 61, 281-288.

Rowe, G.T., 1971. Benthic biomass and surface productivity. In: Costlow, J.D. (Ed.), Fertility of the Sea. Gordon \& Breach, New York, pp. 441-454.

Rumohr, H., Brey, T., Ankar, S., 1987. A compilation of biometric conversion factors for benthic invertebrates of the Baltic Sea. Baltic Mar. Biol. Publ. 9, 1-56.

Salonen, K., Sarvala, J., Hakala, I., Viljanen, L M.-, 1976. The relation of energy and organic content in aquatic invertebrates. Limnol. Oceanogr. 21, 724-730.

Sardá, R., Foreman, K., Valiela, I., 1995. Macroinfauna of a southern New England salt marsh: seasonal dynamics and production. Mar. Biol. 121, 431-445.

Schalk, P.H., Brey, T., Bathmann, U., Arntz, W., Gerdes, D., Diekmann, G., Ekau, W., Gradinger, R., Plötz, J., Nöthig, E., Schnack-Schiel, S.B., Siegel, V., Smetacek, V., Van Franeker, J.A., 1993. Towards a conceptual model for the Weddell Sea ecosystem. In: Christensen, V., Pauly, D. (Eds.), Trophic Models of Aquatic Ecosystems. ICLARM Conference Proc. 26. Manila: ICLARM, pp. 323-337.

Sprung, M., 1993. Estimating macrobenthic secondary production from body weight and biomass: a field test in a non-boreal intertidal habitat. Mar. Ecol. Progr. Ser. 100, 103-109.

Steimle, F.W., 1985. Biomass and estimated productivity of the benthic macrofauna in the New York bight: A stressed coastal area. Estuarine Coastal Shelf Sci. 21, 539-554.

Steimle, F.W., 1987. Production by the benthic fauna. In: Backus, R.H., Bourne, D.W. (Eds.), Georges Bank. MIT Press, Cambridge, MA, pp. 310-314.

Steimle, F.W., Terranova, R.T., 1985. Energetic equivalents of marine organisms from the continental shelf of the temperate Northwest Atlantic. J. Northwest Atlantic Fish. Sci. 6, 117-124.

Suess, E., 1980. Particulate organic carbon flux in the oceans-Surface productivity and oxygen utilization. Nature 288, 260-263. 
Theroux, R.B., Grosstein, M.D., 1987. Benthic fauna. In: Backus, R.H., Bourne, D.W. (Eds.), Georges Bank. MIT Press, Cambridge, MA, pp. 283-295.

Tumbiolo, M.L., Downing, J.A., 1994. An empirical model for the prediction of secondary production in marine benthic invertebrate populations. Mar. Ecol. Progr. Ser. 114, 165-174.

Wacasey, J.W., Atkinson, E.G., 1987. Energy values of marine benthic invertebrates from the Canadian Arctic. Mar. Ecol. Progr. Ser. 39, 243-250.

Walker, M., Tyler, P.A., Billett, D.S.M., 1987. Organic and calorific content of body tissues of deep-sea elapsoid holothurians in the northeast Atlantic Ocean. Mar. Biol. 96, 277-282.

Warwick, R.M., George, C.L., 1980. Annual macrofauna production in an Abra community. In: Collins, M.B. (Ed.), Industrialized Embayments and their Environmental Problems. Pergamon, Oxford, pp. 517-538.

Warwick, R.M., Price, R., 1975. Macrofauna production in an estuarine mud-flat. J. Mar. Biol. Assoc. UK 55, $1-18$.

Warwick, R.M., George, C.L., Davies, J.R., 1978. Annual macrofauna production in a Venus community. Estuarine Coastal Shelf Sci. 7, 215-241.

Warwick, R.M., Joint, I.R., Radford, P.J., 1979. Secondary production of the benthos in an estuarine enviroment. In: Jefferies, R.L. (Ed.), Ecological Processes in Coastal Environments. Blackwell Scientific, Oxford, pp. 429-450.

Wolff, W.J., de Wolf, L., 1977. Biomass and production of zoobenthos in the Grevelingen Estuary, The Netherlands. Estuarine Coastal Shelf Sci. 5, 1-24. 